\title{
Review: Testosterone Replacement Therapy. Through 2018 Updates, should we Still Consider it a Prostate Cancer Risk Factor?
}

\author{
Mohamed Noureldin* \\ Senior Clinical Fellow of Urology, Imperial College NHS Foundation Trust, United Kingdom
}

Submission: January 28, 2019; Published: February 28, 2019

*Corresponding author: Mohamed Noureldin, Senior Clinical Fellow of Urology, Imperial College NHS Foundation Trust, Landon, United Kingdom

\section{Introduction}

Testosterone Replacement Therapy (TRT) usage has great benefits on men's health and do improve more the symptoms that could occur in those who are complaining of hypogonadism or andropause. However, it is classically known the oncological risks that may be caused due to its usage on the prostate, that's why it was used with cautious. Recently many articles appeared in the last few years refuting this and evidencing the concept that there is no harm of their usage with those who are at risk of prostate cancer or even have treated prostate cancer. In this short review, it is aimed to review the literature that support this evidence published in 2018 on the PubMed.

\section{Discussion}

The decrease of the serum Testosterone levels causes what is known as hypogonadism which is manifested by decrease in libido, erectile dysfunction, fatigue and depression. This condition has a counted prevalence in men above the age of 50 years old. On the other side prostate cancer incidence starts to sharpen up after this age also and that's why most of the screening programmes recommends starting the screening for men without family history at the age of 50 years old. As a historical knowledge it is known that Testosterone fuels the prostate cancer, this originally comes from 1941 when Dr Charles Huggins found that castration resulted in regression of the metastatic PCa and the debate is on since then [1].

\section{Is it important to use it?}

Restoring testosterone levels to within the normal range by using testosterone replacement therapy can improve many of the effects of hypogonadism. Most importantly, this also include beneficial effects on mood, energy levels and patients' sense of well-being, sexual function, lean body mass and muscle strength, erythropoiesis and bone mineral density in addition to its use to improve other clinical symptoms of the metabolic syndrome, which presents as visceral obesity, hypertension, diabetes mellitus, and dyslipidaemia and are considered to be a potential risk for cardiovascular disease and cerebral apoplexy [2].

\section{Recent Evidence of its Safety on the Prostate}

Looking for the recent evidences and literature supporting that there is no correlation between the TRT and the prostate cancer which is challenging the classic opinion, Walsh TJ et al. [3] identified 56,833 men who initiated testosterone treatment for low testosterone levels and they were followed up for 3 years with PSA compared to non-treated group and a total of 1,439 prostate cancers were diagnosed; 848 were diagnosed among untreated and 591 among testosterone-treated men which was not a big statistical difference. So, they concluded that there is no much increase in the risk of prostate cancer development in those who are treated with testosterone in compared to nontreated group. However, the main pitfall of this study its short duration and it was recommended to have the same study for longer time up to 10 years.

A review by Torres et al. [4] summarized some evidences from the literature by different studies that compared patient who have a sort of treated prostate cancer and normal person and it was concluded at the end of the review that there are a lot of reassuring data that TRT doesn't have a direct risk in causing PCa but yet there is still a small number that have a prostate cancer under TRT so a larger number studies and longer duration of follow up is recommended. Finally, a 2015 retrospective review of 98 hypogonadal men treated with TRT after radiation therapy for PCa and followed for about 40 months, they showed a rise in the levels of serum testosterone but there was no significant increase in mean PSA [5].

\section{Conclusion}

To our knowledge in 2018 there was limited published evidence on this subject. However, the new data keeping with 
the flow of the new evidence that there is conservative safety in TRT usage as regard its prostate cancer potential risk.

\section{References}

1. Droz JP, Aapro M, Balducci L, Boyle H, Van den Broeck T, et al (2014) Management of prostate cancer in older patients: updated recommendations of a working group of the International Society of Geriatric Oncology. Lancet Oncol 15(9): e404-414.

2. Bassil N, Alkaade S, Morley JE (2009) The benefits and risks of testosterone replacement therapy: a review. Ther clin risk manag 5:427-448.

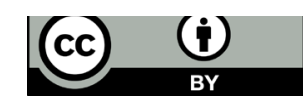

This work is licensed under Creative Commons Attribution 4.0 Licens DOI: 10.19080/JETR.2019.04.555630
3. Walsh TJ, Shores MM, Krakauer CA, Forsberg CW, Fox AE, et al. (2018) Testosterone treatment and the risk of aggressive prostate cancer in men with low testosterone levels. PloS one 13(6): e0199194.

4. Torres LO (2018) Do we have enough evidences that make you safe to treat a man with hypogonadism one year after a radical prostatectomy for prostate cancer? | Opinion: YES. Int braz J urol 44(1): 4-7.

5. Rodriguez KM, Pastuszak AW, Khera M (2018) The Role of Testosterone Therapy in the Setting of Prostate Cancer. Curr urol rep 19(8):67.

Your next submission with Juniper Publishers
will reach you the below assets
- Quality Editorial service
- Swift Peer Review
- Reprints availability
- E-prints Service
- Manuscript Podcast for convenient understanding
- Global attainment for your research
- Manuscript accessibility in different formats
( Pdf, E-pub, Full Text, Audio)
- Unceasing customer service
Track the below URL for one-step submission
https://juniperpublishers.com/online-submission.php

